\title{
Community Driven Development Policy as a Strategy for Rural Development: A Case ofFadama III Crop Production Co-Operative Societies in Anambra, Enugu and Imo States of Nigeria
}

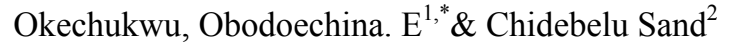 \\ ${ }^{1}$ Department of Co-operative Economics and Management, NnamdiAzikiwe University, Awka Anambra State, \\ Nigeria \\ ${ }^{2}$ Department of Agricultural Economics, University of Nigeria, Nsukka, Enug State, Nigeria \\ *Correspondence: Department of Co-operative Economics and Management, NnamdiAzikiwe University, Awka \\ Anambra State, Nigeria. E-mail: emobok79@gmail.com
}

Received: March 23, 2015

Accepted: July 20, $2015 \quad$ Online Published: October 12, 2015

doi:10.5430/mos.v2n4p54

URL: http://dx.doi.org/10.5430/mos.v2n4p54

\begin{abstract}
This work evaluates community-driven development policy as a strategy for rural development looking at crop farmers' co-operative societies of the Fadama III Project in Anambra, Enugu and Imo States of Nigeria. The study estimated annual incomes and productive resources used by the farmers before and after joining the project and identified constraints to the realization of project objectives. Descriptive statistics such as frequency counts, means and percentages, were used to analyze data on socio-economic characteristics of the respondents, their incomes and constraints to effective realization of the project objectives while multiple regression model using the ordinary least squares (OLS) approach was used to determine the influence of socio-economic characteristics of the farmers on their income before and after joining the project. Hypotheses were tested using t-statistic in Two-Sample T-test. The significant difference between productive resources utilized by the farmers before and after joining the project implies goodness of the policy which constitutes an injection of capital into the rural economy. The crop farmers' annual incomes before and after joining the project were significantly determined by distance to the market, farm size, extension visits and value of productive resources. Irregular fund disbursement topped the list of nine constraints to effective realization of project objectives arranged in descending order of seriousness. Early and prompt release of productive resources and cash counterpart contributions to the farmers, provision of more extension agents, services and logistics for the farmers and reduction of users' cash contribution will ensure improved productivity, income and project sustainability.
\end{abstract}

Keywords: community-driven-development; co-operatives; Anambra State; Enugu State; Imo State; Fadama III project; income; productive resources; Significant; Sustainable

\section{Introduction}

Community-driven development (CDD) is an approach that gives control over planning decisions and investment resources for local development projects to community groups. The concept of community is one of those terms social science particularly sociology has not been able to find a common definition. There were ninety-four discrete definitions of the term by the mid-1950s. The word "community" is derived from the old French comunete which is derived from the Latin communitas (from Latin communits, things held in common), a broad term for fellowship or organized society (Oxford University, 2014). Community often refers to a group that is organized around common values and is attributed with social cohesion within a shared geographical location, generally in social units larger than a household. It can be said to be a unity of social organization or structure which comes into being when social interactions become regularized or patterned in such a way that the unity becomes an identifiable entity. In human communities, intent, belief, resources, preferences, needs, risks, and a number of other conditions may be present and common, affecting the identity of the participants and their degree of cohesiveness. These attributes of community participation and cohesiveness might have influenced the Nigerian government's decision to adopt the strategy of Community-Driven-Development in designing the Fadama III Project sponsored by the World Bank. 
Community-driven development (CDD) programmes operate on the principles of local empowerment, participatory governance, demand-responsiveness, administrative autonomy, greater downward accountability, and enhanced local capacity.

Rural development, according to Umebali (2008), is a process whereby concerted efforts are made in order to facilitate significant increases in rural resource productivity with the central objective of enhancing rural income and increasing employment opportunities in rural communities for rural dwellers to remain in the area or as an integrated approach to food production, provision of physical, social and institutional infrastructures with an ultimate goal of bringing about qualitative changes which culminate in improved standard of living of rural population. Attempts in the past aimed at opening up the rural areas to increase the productivity and enhance the farmers' income, according to Henri-Ukoha, Ohajianya, Nwosu, Onyeagocha, and Nwankwo, (2011) include: National Accelerated Food production Programme (1974), River Basins Development Authorities (1975), Integrated Rural Development Projects (1980), Agricultural Development Programme (ADP) (1985), National Directorate of foods, Roads and Rural Infrastructure (1988), National Agricultural Research Projects - World Bank Assisted(1991), National Programme on Food Security(1999), The Presidential Initiative on Livestock etc for production, processing and export (2002) and a host of other programmes designed. The impact of these policies, however, has been shadowed (Baba and Singh, 1998) as the rural areas are still impoverished and undeveloped.

The development objective of Fadama III is to increase the income of the users of rural land and water resources on sustainable basis. It relies on the facilitation of demand-driven investment and empowerment of local community groups and to improve productivity and land quality. Successive governments, collaborating with various development partners, have invested huge sums of money in poverty reduction projects especially in rural areas but not much have been achieved in terms of sustained growth and improved living standard in the rural communities. It is against this background that the Third National Fadama Development project was embarked upon by the 36 states and the Federal Capital Territory (FCT) mainly to diversify agricultural production (Enugu State Fadama Coordination Office, 2008).

The choice of co-operatives as agent institution for the project might have been governed by United Nations Department of Economic and Social Affairs (UNDESA), (2009), observation that co-operatives, as economic enterprises and as self-help organizations, play a meaningful role in uplifting the socio-economic conditions of their members and their local communities. Over the years, co-operative enterprises have successfully operated locally-owned people-centred businesses while also serving as catalysts for social organization and cohesion. With their concern for their members and communities, they represent a model of economic enterprise that places high regard for democratic and human values and respect for the environment.

\section{Fadama III Context in the States}

Fadama III Project is a comprehensive five-year action programme developed by the then Federal Ministry of Agriculture and Water Resources (FMAWR) in collaboration with the Federal Ministry of Environment(FME) and other federal and state government ministries, local governments and key stakeholders (donors, private operators, NGOs). The Project which is anchored on community-driven development (CDD) approach is a World Bank assisted project implemented beginning from July 2008 and terminating in December 2013. It is one of such projects enunciated by the Federal government of Nigeria predicated on the development of the rural areas for the reduction of poverty, unemployment and inequality. It was established to ensure all year round production of crops in all the states of the federation through the exploitation of shallow aquifers and surface water potentials in each state

The word "Fadama" is a Hausa name for irrigable land, usually low-lying, and flood plain areas underlined by shallow aquifers found along Nigeria's river system (Echeme and Nwachukwu, 2010). According to Nwachukwu, et al, (2009), Fadama also refers to a seasonally flooded area used for farming during the dry season. When Fadama spread out over a large area, they are often called 'wetlands' [Blench \&Ingawa, (2004 and Nkonya, et al, (2008)]. Wetlands are recognized by the Ramsar 3 Convention of 1971, according to Anon (2004), as areas of marsh, fen, peat land or water, whether natural or artificial, permanent or temporary, with water that is static or flowing, fresh, brackish or salt, including areas of marine water the depth of which at low tide does not exceed six meters. The Fadama Project adopts community-driven development approach such that the benefitting groups - Fadama Users Groups (FUG) have the opportunity of choosing adoptable activity that can attract the support of the World Bank (Echeme\&Nwachukwu, 2010).

According to United Nations (2010) the Fadama III Project development objective is to increase the income of users of rural land and water resources on a sustainable basis in order to reduce rural poverty, increase food security as well as contribute to the achievement of the Millennium Development Goals (MDGs). Its Community Driven Development 
(CDD) approach is meant to concede project initiation, planning and implementation to the benefiting communities with the assistance of facilitators. Local communities, under the umbrella of Fadama Community Associations (FCAs) and Fadama User Groups (FUGs), oversee the design and implementation of the project and are empowered through skills and capacity-building to improve their livelihoods by increasing income generating activities.

One major thrust of Fadama Projects is to extend the farming season beyond the rainy season through irrigated agriculture (Ajayi\&Nwalieji, 2010). The NFDP has the general goal of increasing food production in the states through expanded cultivation, using simple small-scale irrigation facilities with appropriate technologies. It was aimed at increasing the land area under cultivation by providing an all-year round cropping of marketable and high-valued crops such as cereals (maize and rice. The increase in the total population of these crops annually would increase the incomes of the farmers and raise their standard of living.

Fadama III seeks to empower the users through collective decision-making on how to effectively and efficiently allocate and manage resources for their livelihood activities. The management of the Project is based on a decentralized, demand-responsive structure that grants community organizations as much decision-making authority as possible. It is meant to promote community ownership of and responsibility for operations and maintenance of infrastructure investments (Federal Ministry of Agriculture and Water Resources, (FMAWR) 2009).

Under the scheme, government agencies will hands-off the provision of production, marketing, processing, financial and advisory services to project clients to private sector. The role of government will only be limited to providing a conducive policy and institutional environment through investments in improving relevant physical infrastructure as well as make provision for goods of a public nature. Government would also put in place an appropriate regulatory system to ensure that project clients obtain regular supplies of the right quality of inputs and technical advice and up-to-date market information (ADF, 2003).

The project is expected to help foster credit intermediaries or promote revolving savings and credit associations that can help the poor to access productive assets. It will address the low capacity of the poor farmers to manage productive assets efficiently through increased training and development of complementary services, such as advisory services.

\subsection{Anambra State}

Anambra State was created in 1991. Its name is an anglicized version of the original 'OmaMbala', the name of the river now known as Anambra which the state is named after The Capital and the Seat of Government is Awka. Onitsha and Nnewi are the biggest commercial and industrial cities, respectively. The dominant ethnic group is Igbo (98\%) followed by Igala (2\%), (Canback Global, 2008). Wikipedia Organisation (2013) documented that Anambra occupies an area of $4,844 \mathrm{~km}^{2}(1,870.3 \mathrm{sq} \mathrm{mi})$ and ranks $10^{\text {th }}$ in population in Nigeria with a population of $4,055,048$ given by the 2006 census. With a population density of $837.1 / \mathrm{km}^{2}(2,168.2 / \mathrm{sq} \mathrm{mi})$, it ranks second to Lagos State. The State has 21 Local Government Areas and politically shared equal into three senatorial zones. Twenty out of the 21 Local Government Areas in the state are participating in the project. Anambra State is predominantly occupied by the Igbo ethnic group of Nigeria, who by nature are farmers, fishermen, craftsmen and traders. It has an almost 100 percent arable soil. Among crops grown by farmers in the state are yam, palm produce, rice, cassava, cocoyam, vegetables, and different varieties of fruit trees among others.

The State experiences dry season from late October to early May and has at least six dry months in the year. The vegetation of the state consists of rainforest, wooden savannah and grasslands. The State is drained by five major rivers and their tributaries. These are the River Niger, Anambra River, Mamu/Ezu River, Idemili River and River Ulasi. In addition to these, there are smaller perennial streams like the Oyi, Nkisi, and Obizi. In-land valley ponds and lakes occur, with the Agulu Lake draining a collection of towns in the state (Ajayi\&Nwalieji, 2010). This drainage makes the state very conducive for agricultural activities.

\subsection{Enugu State}

Enugu State was created on August 27, 1991 with the city of Enugu, euphemistically referred to as the "coal city", as its capital. The state derives its name from the capital city which was established in 1912 as a small coal mining town, but later grew to become the capital of the former Eastern Region of Nigeria. Enugu remained the capital of the East Central State of Nigeria, one of the three states carved out of the former Easthern Region in 1967. The State, with 17 local government areas, is located in a tropical rain forest zone which implies existence a tropical savanna climate. The climate is humid and this humidity is at its highest between March and November. For the whole of Enugu State the mean daily temperature is $26.7^{\circ} \mathrm{C}\left(80.1^{\circ} \mathrm{F}\right)$.

Enugu State is traversed by a number of rivers and streams prominent among them are Adada. Iyoko, Idodo, Ekulu, Oji, Ebonyi and Mamu/Ezu Rivers. Economically, the state is predominantly rural and agrarian, with a substantial 
proportion of its working population engaged in farming, although trading (18.8\%) and services (12.9\%) are also important. The main produce are yam tubers, palm produce and rice. The State is predominantly occupied by the Igbo ethnic group (Adeyemi, 2011).

\subsection{Imo State}

Imo State, which derived its name from Imo River, was created in 1991. It covers an area of about 5,100sq km with an estimated population of about 4.8 million and a population density that varies from 230-1,400 people per square kilometer. The State lies within latitudes $4^{\circ} 45^{\prime} \mathrm{N}$ and $7^{\circ} 15^{\prime} \mathrm{N}$, and longitude $6^{\circ} 50^{\prime} \mathrm{E}$ and $7^{\circ} 25^{\prime} \mathrm{E}$. It ranks $13^{\text {th }}$ in population in Nigeria. It is culturally a homogeneous state as it is a predominantly an Igbo speaking state with minor differences in dialects. The State is divided into 27 local government areas.

The main rivers draining the state are Imo, Otamiri, Njaba and Ulasi rivers, all of which have very few tributaries. The Ogutalake also drains a number of towns in the State.High temperature and humidity experienced in the state favour luxuriant plant growth, which ideally should produce the climax vegetation of the tropical rain forest. Economic trees like the iroko, mahogany, obeche, gmelina, bamboo, rubber and oil palm predominate. However, the main agricultural produce in Imo State are palm produce, cocoa and rubber while major staple crops are yam, cassava, cocoyam and maize. (Adeyemi, 2011).

\section{Theoretical Framework}

The researcher based this work on Collective Action Theory. Collective action is traditionally defined as any action aiming at improving the group's conditions (such as status or power), which is enacted by a representative of the group (Wright, Taylor, \&Moghaddam, 1990). Tajfel and Turner (1979) posited that people strive to achieve and maintain positive social identities associated with their group memberships. In their Social Identity Theory, Tajfeland Turner (1979) argued that where a group membership is disadvantaged (for example, low status), social identity theory (SIT) points at three variables in the evocation of collective action to improve conditions for the group viz permeability of group boundaries, legitimacy of the inter-group structures, and the stability of these relationships. For example, when disadvantaged groups perceive inter-group status relationships as illegitimate and unstable, collective action is predicted to occur in an attempt to change status structures for the betterment of the disadvantaged group.

Pandolfelli, Meinzen-Dick, and Dohrn (2008), saw collective action as both the process by which voluntary institutions are created and maintained and the groups that decide to act together. Collective action plays a vital role in many people's lives, through such areas as income generation, risk reduction, public service provision, and the management of natural resources. Integrating both women and men into collective action can lead to greater group effectiveness. In many instances, the gender composition of groups is an important determinant of effective collective action, especially for natural resource management in two key dimensions: (i) the ability of groups to meet their immediate purposes, whether that purpose is the management of a natural-resource or the disbursement of funds to members of a burial group, and (ii) the process by which the group works to meet that purpose. Specific measures of effectiveness might include tangible indicators such as economic returns to group members, compliance with rules, transparency and accountability in managing funds, or the incidence and severity of conflicts, as well as less tangible indicators, such as members' satisfaction with the group (Pandolfelli, Meinzen-Dick, \&Dohrn, 2008). This conforms with the co-operative principles of open membership and gender equality.

Marshall (1988) suggests that collective action is an action taken by a group (either directly or on its behalf through an organization) in pursuit of member's perceived shared interest. He went on in his work to maintain that collective action requires involvement of a group of people; share of interest within the group; common action which works in the pursuit of the shared interest and voluntary action to distinguish it from hired labour. Collective action is also seen as a voluntary action taken by a group of people to achieve common interest. Co-operative, as voluntary association of independent individuals who come together in order to solve their socio-economic problems, requires collective action to succeed. Okechukwu (2001) stated that all known definitions of co-operative tend to highlight the following about co-operatives: co-operation is a form of organization of people; the people are rational beings; they are together on equality basis; are there for the promotion of socio-economic interest of themselves; and are democratically managed.

Based on the premise above, the theory of collective action becomes apt in this work especially as Fadama Users' Groups are organized, incorporated and managed as co-operative organisations. This is buttressed more by Chavez (2003) who opined that collective theory definition, principles and practice directly or indirectly relate to co-operative seven internationally recognized principles of voluntary and open membership, member economic participation; co-operation among co-operatives, concern for community etc. According to Dick, Gregorio, and McCarthy (2004) 
collective action theory is a theory that is very useful in agriculture, rural resource management, and rural development programmes. These are the hallmark of Fadama Users Groups.

This work also took cognizance of Wilcox Community Participation Theory which offers a comprehensive framework for thinking about involvement, empowerment and partnership by communities in the course of development projects. The theoryproposed a five-rung ladder of participation which relates to the stance an organisation promoting participation may take:

i) Information: merely telling people what is planned, ii) Consultation: offering some options, listening to feedback, but not allowing new ideas, iii) Deciding together: encouraging additional options and ideas, and providing opportunities for joint decision-making. iv) Acting together: not only do different interests decide together on what is best, they form a partnership to carry it out and v) Supporting independent community interests: local groups or organisations are offered funds, advice or other support to develop their own agendas within guidelines. This is the premise CDD strategy was designed to function upon.

The Community Driven Development (CDD) approach is meant to concede project initiation, planning and implementation to the benefiting communities with the assistance of facilitators. Local communities, under the umbrella of Fadama Community Associations (FCAs) and Fadama User Groups (FUGs), oversee the design and implementation of the project and are empowered through skills and capacity-building to improve their livelihoods by increasing income generating activities. This is in complete resonance with the community participation theory put up by Wilcox. As Wilson and Wide, (2003) had it, the community is recognized and valued as an equal partner at all stages of the process, there is a meaningful community representation on all decisions making bodies from initiation, all community members have an opportunity to participate and communities have access to and control over resources.

\section{Materials and Methods}

This study centered on Fadama User Groups (FUGs) crop farmer-members within Anambra, Enugu and Imo States of Nigeria. It was aimed at determining through their performance, the effectiveness of community driven development approach of Fadama III Project towards rural development. The study tried to determine if there is any significant difference between the fortunes of crop farmer-members of the FUGs before and after joining the scheme with respect to their income and values of productive resources used as well as the effects of their socio-economic characteristics on their incomes.

The population for this study consisted of all the FUG crop farmer-members within the three States of Anambra, Enugu and Imo. A multistage purposive sampling method was adopted to select respondents to ensure full coverage of the study area. In the first stage four LGAs were purposively selected from Anambra State, and three from Enugu and Imo States respectively. Anambra State had one LGA more than Imo and Enugu States because it had more LGAs involved in crop farming in the project than the other two States, giving a total of 10 LGAs. In the second stage, four Fadama User Groups (FUGs) were purposively selected from each of the 10 selected LGAs to arrive at a total of 40 FUGs. In the third stage, six crop farmers were selected from each selected FUG to give a total of 240 (Anambra=96, Enugu=72, $\operatorname{Im} 0=72)$ crop farmer-members for the study. This constituted the final sample size for the study.

Primary data were collected from crop farmer-members of the FUGs using well structured and pre-tested questionnaires, scheduled interviews and panel discussions. Primary data were collected on socio-economic characteristics of the respondents, their income, access to productive resources and constraints to effective realization of the project objectives. Data on constraints were collected by means of a 5-point Likert Scale. Members of the FUGs responded to any of the five response ratings of Strongly Agree (4), Agree (3); Disagree (2); Strongly Disagree (1) and Indifferent (0);

Descriptive statistics such as frequency counts, means and percentages, were used to analyze data on socio-economic characteristics of the respondents, their incomes and constraints to effective realization of the project objectives while multiple regression model using the ordinary least squares (OLS) approach was used to determine the influence of socio-economic characteristics of the farmers on their income before and after joining the project.

The multiple regression model is implicitly specified as follows:

$\mathrm{INC}=\mathrm{f}(\mathrm{EDU}, \mathrm{AGE}, \mathrm{ASI}, \mathrm{DTM}, \mathrm{FFS}, \mathrm{FAS}, \mathrm{ETV}, \mathrm{GEN}, \mathrm{EXP}, \mathrm{PDR})+\mathrm{e}$

Where:

$\mathrm{INC}=$ Income generated by the FUG crop farmers; 
EDU = Education level (years);

$\mathrm{AGE}=$ Age of the farmer (years);

ASI $=$ Availability of special infrastructure (dummy: available $=1$; otherwise $=0$ );

DTM $=$ Distance to market (kilometers);

FFS = Farmer's farm size (hectares);

FAS $=$ Family size (number);

$\mathrm{ETV}=$ Extension visit/contacts (number);

GEN $=$ Gender $($ Male $=1$; Female $=2)$;

$\mathrm{EXP}=$ Farmer's farming experience (years); and

$\mathrm{PDR}=$ Productive resources (available $=1$; otherwise $=2)$

Four functional forms of the regression model were tried, namely, linear, exponential, semi-log, and double-log. Output of the form with the highest value of coefficient of multiple determination $\left(\mathrm{R}^{2}\right)$, highest number of significant variables and F-statistics value were selected as the lead equation. The explicit versions of the four functional forms are as follows:

Linear: INC $=b_{0}+b_{1}$ EDU $+b_{2}$ AGE $+b_{3}$ ASI $+b_{4}$ DTM $+b_{5}$ FFS $+b_{6}$ FAS $+b_{7}$ ETV $+b_{8}$ GEN $+b_{9}$ EXP $+b_{10}$ PDR $+e_{i}$ Exponential: InINC $=b_{0}+b_{1}$ EDU $+b_{2}$ AGE $+b_{3} A S I+b_{4}$ DTM $+b_{5}$ FFS $+b_{6}$ FAS $+b_{7}$ ETV $+b_{8}$ GEN $+b_{9}$ EXP + $\mathrm{b}_{10} \mathrm{PDR}+\mathrm{e}_{\mathrm{i}}$

Semi-log: INC $=b_{0}+b_{1} \operatorname{InEDU}+b_{2} \operatorname{InAGE}+b_{3} \operatorname{InASI}+b_{4} \operatorname{InDTM}+b_{5} \operatorname{InFFS}+b_{6} \operatorname{InFAS}+b_{7} \operatorname{InETV}+b_{8} \operatorname{InGEN}+$ $\mathrm{b}_{9} \operatorname{InEXP}+\mathrm{b}_{10} \operatorname{InPDR}+\mathrm{e}_{\mathrm{i}}$

Double-log: InINC $=b_{0}+b_{1} \operatorname{InEDU}+b_{2} \operatorname{InAGE}+b_{3} \operatorname{InASI}+b_{4} \operatorname{InDTM}+b_{5} \operatorname{InFFS}+b_{6} \operatorname{InFAS}+b_{7} \operatorname{InETV}+b_{8} \operatorname{InGEN}$ $+b_{9} \operatorname{InEXP}+b_{10} \operatorname{InPDR}+e_{i}$

The $b_{0}$ and the $b_{i} s$ are the parameters to be estimated and the $e_{i}$ is the error term meant to capture errors arising from mistakes in specifications, exclusions, inclusions, data collection. In is the logarithm to base 10 . The acronyms - INC, EDU, AGE, ASI, DTM, FFS, FAS, ETV, GEN, EXP, PDR- are as earlier defined.

\section{Results and Discussions}

\subsection{Socio-economic Characteristics of the FUG crop Farmers}

A summary of the socio-economic characteristics of the crop farmers is shown in Table 1. The results reveal that in Anambra State, $48.96 \%$ were males while $51.04 \%$ were females, in Enugu State, $75 \%$ were males and 25\% were females while Imo State had $59.72 \%$ as males and $40.28 \%$ as females. The large percentage of women farmers in the states of study is an indication of the extent Fadama III Project recognized and projected the capabilities of females in agriculture.

The average age of the farmers falls within the working age bracket of 20 to 59 years showing prospects for greater productivity which the Fadama III project tends to achieve.In Anambra State, $87.5 \%$ fell within this active age while only $12.5 \%$ were 60 years and above, in Enugu State, $65.28 \%$ fell within this age bracket while $34.72 \%$ had attained the age of 60 years and above while in Imo State, $18.06 \%$ of the respondents had attained 60 years and above while the remaining $81.94 \%$ belonged to the active age range. The study reveals that the farming business is dominated by an age bracket considered to be economically active and highly productive (Ebewore, 2010).This implied that Fadama III project successfully aided a reduction in rural unemployment which is an indication of development.

Marriage in these States, apart from being a status and maturity symbol, is a necessity for an average farmer for the obvious reason of raising children who will add to the family labour and reduce production cost. The analysis showed that in Anambra State, $98.96 \%$ of the respondents were married, $94.44 \%$ in Enugu State, and $97.22 \%$ in Imo State. However, the more the children the greater the dependency ratio and a reduction in the farmer's net income. Large household sizes have been noted to have correlation with food insecurity and poverty especially when the household head is engaged in agriculture as the main source of livelihood and income (Ike and Uzokwe, 2011). The average number of education years attained by the farmers were 7,9 and 8years respectively implying a post primary education. Good education enhances managerial, organizational effectiveness and efficiency of the farmer. These attributes will be manifested in his productivity and net income. 
Table 1. Socio-Economic Characteristics of the FUG Crop Farmers

\begin{tabular}{|c|c|c|c|}
\hline & Anambra & Enugu & Imo \\
\hline Variables & $(\mathrm{N}=96)$ Percentage & $(\mathrm{N}=72) \quad$ Percentage & $(\mathrm{N}=72)$ Percentage \\
\hline \multicolumn{4}{|l|}{ Gender } \\
\hline Male & 48.96 & 75 & 59.72 \\
\hline Female & 51.04 & 25 & 40.28 \\
\hline \multicolumn{4}{|c|}{ Age (years) } \\
\hline $20-39$ & 18.75 & 09.72 & 18.06 \\
\hline $40-59$ & 68.75 & 55.56 & 63.88 \\
\hline$\geq 60$ & 12.50 & 34.72 & 18.06 \\
\hline Average & 47 & 51 & 48 \\
\hline \multicolumn{4}{|c|}{ Marital status } \\
\hline Married & 98.96 & 94.44 & 97.22 \\
\hline Single & 01.04 & 05.56 & 02.78 \\
\hline \multicolumn{4}{|c|}{ Family size } \\
\hline $1-4$ & 25 & 08.33 & 13.89 \\
\hline $5-9$ & 65.63 & 76.39 & 69.44 \\
\hline$\geq 10$ & 09.37 & 15.28 & 16.67 \\
\hline Average & 6 & 7 & 6 \\
\hline \multicolumn{4}{|c|}{ Education (years) } \\
\hline $0-6$ & 48.96 & 16.67 & 36.11 \\
\hline $7-12$ & 43.75 & 63.89 & 58.33 \\
\hline$\geq 13$ & 07.29 & 19.44 & 05.56 \\
\hline Average & 7 & 9 & 8 \\
\hline \multicolumn{4}{|c|}{ FarmingExperience (years) } \\
\hline $1-20$ & 45.83 & 22.78 & 59.72 \\
\hline $21-40$ & 51.04 & 45.83 & 40.28 \\
\hline $41-60$ & 03.13 & 09.72 & -- \\
\hline Average & 22 & 24 & 18 \\
\hline \multicolumn{4}{|c|}{ Farm size (hectares) } \\
\hline $0.1-2$ & 83.33 & 56.96 & 66.67 \\
\hline $2.1-4$ & 13.54 & 38.88 & 23.61 \\
\hline$\geq 4.1$ & 03.13 & 04.16 & 09.72 \\
\hline Average & 1.4 & 1.9 & 1.8 \\
\hline \multicolumn{4}{|c|}{ Distance toMarket $(\mathrm{km})$} \\
\hline $1-5$ & 51.04 & 80.56 & 61.11 \\
\hline $6-10$ & 15.63 & 13.88 & 29.17 \\
\hline$>10$ & 33.33 & 05.56 & 09.72 \\
\hline Average & 6 & 4 & 5 \\
\hline
\end{tabular}

Source: Field survey 2014.

\subsection{Estimated Income of the Farmers before and after Joining the Fadama III Project}

Table 2 presents the result of the estimated income of the farmers before and after joining the project. The study revealed that cassava earned the highest income in Anambra State before the Project with $\$ 13,112,555$ (41.56\%), followed by rice with $\$ 11,982,200$ (37.98\%), yam is the next with $\$ 4,963,980$ (15.73\%) and plantain contributed the least with $\$ 215,100(0.67 \%)$. After joining the project, rice topped the list this time with $\$ 50,164,260(48.02 \%)$ overtaking cassava which gave the farmers highest income before joining the project. The improved position of rice in the Anambra State could be in response to Federal Government's policy on increased local production of rice to reduce dependence on import. Rice was followed by cassava with $\$ 37,110,783$ (35.52\%), yams with $\$ 12,020,000$ (11.51\%) and the least was plantain with $\$ 232,400(0.22 \%)$. 
Table 2. Estimated Income of the Farmers before and after Joining the Fadama Project

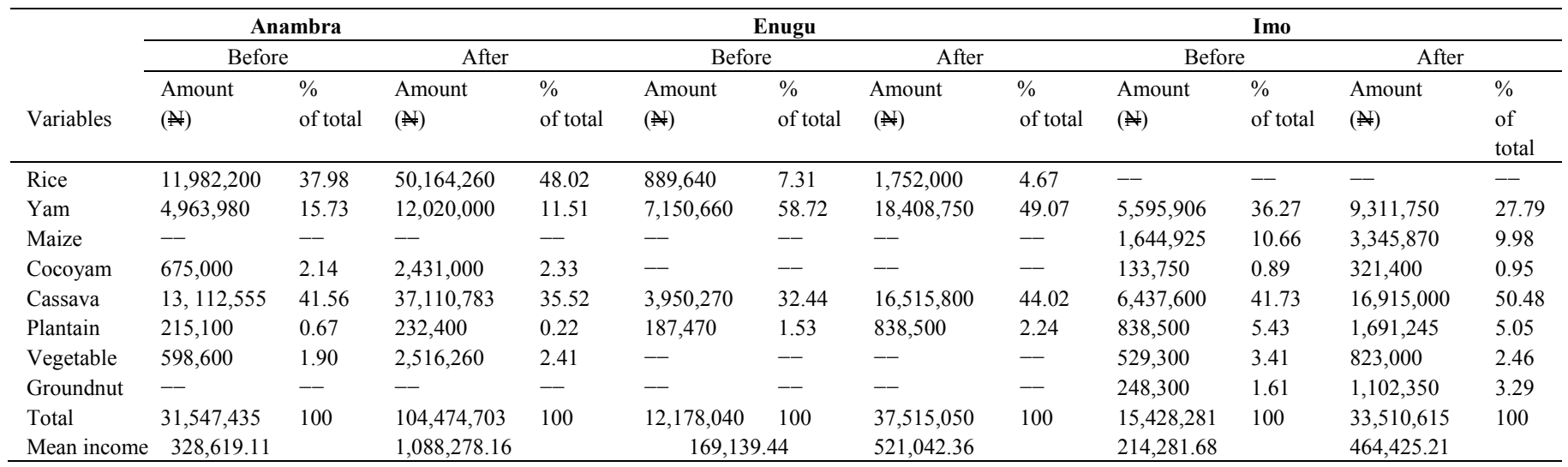

Source: Field survey, 2014.

In Enugu State, prior to the project, yams earned the highest income with $\$ 7,150,660(58.72 \%)$, followed by cassava with $\$ 3,950,270$ (32.44\%), next is rice with $\$ 889,640$ (7.31\%) while plantain with $\$ 187,470$ (1.53\%) is the least. Yams still topped the list after joining the project with $\$ 18,408,750$ (49.07\%) followed by cassava with $\$ 16,515,800$ $(44.02 \%)$, then rice with $\$ 1,752,000$ (4.67\%) while plantain came last with $\$ 838,500(2.24 \%)$.

In Imo State, cassava topped the list with $\$ 6,437,600$ (41.73\%) followed by yams with $\$ 5,595,900$ (36.27\%), followed by maize with $\$ 1,644,925$ (10.66\%). Cocoyam contributed the least with $\$ 133,750(0.89 \%)$. After joining the project cassava still topped the list with $\$ 16,915,000(50.48 \%)$ followed by yams with $\$ 9,311,750(27.79 \%)$, and maize with N3,345,870 (9.98\%) while cocoyam earned the least with $\$ 321,400$ (0.95\%).

Mean incomes of $\$ 328,619.11, \$ 169,39.44$, and $\$ 214,281.68$ were realized by the farmers in Anambra, Enugu and Imo States respectively prior to the project but after joining the project the FUG crop farmers realized estimated mean incomes of $\$ 1,088,278.16, \$ 521,042.36$, and $\$ 464,425.21$ in Anambra, Enugu and Imo States respectively. This implied that the FUG crop farmers properly utilized the productive resources made available to them to enhance their income which is a positive indication of development as a result of the Fadama III project.

\subsection{Differences in Mean Incomes of the FUG Crop Farmers before and after joining the Fadama Project}

Table 3. Estimated Difference in Means of Income of Farmers Before and After Joining the Project

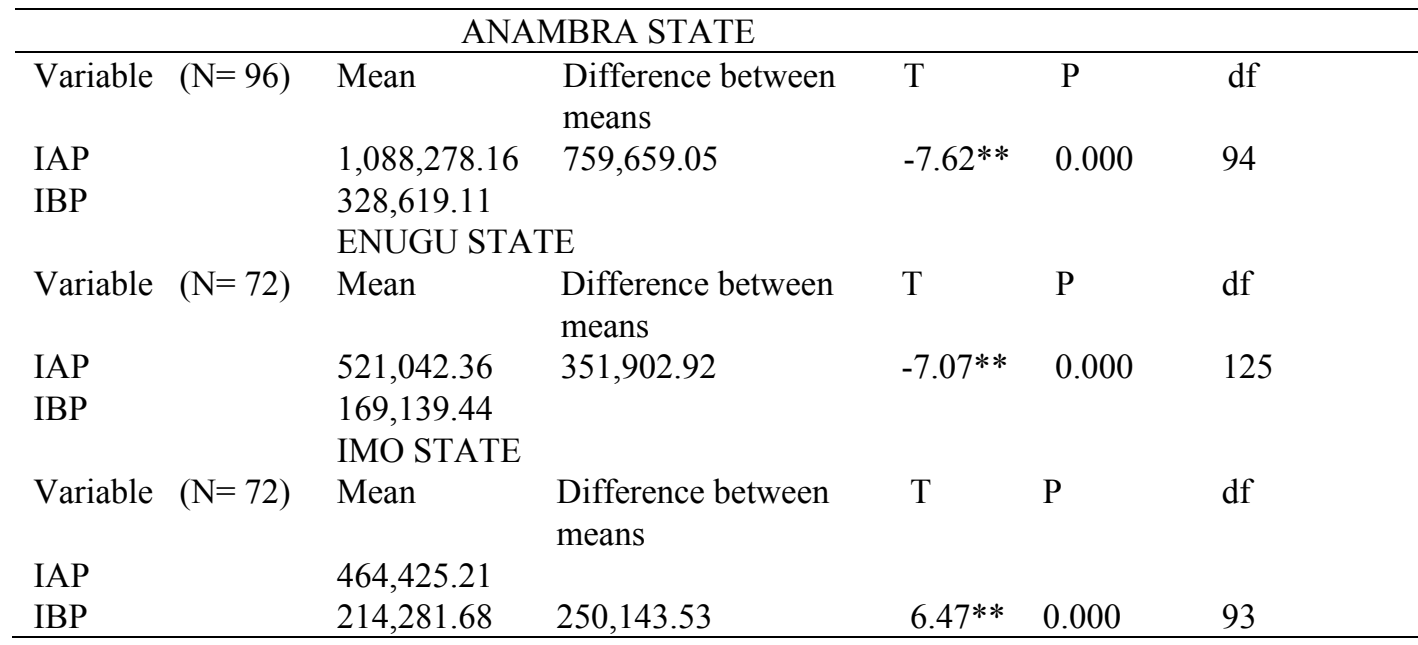

Notes: IAP $=$ Income after joining the project; IBP $=$ Income before joining the project. $\mathrm{N}=$ Number of respondents. $* *$ $=$ Significant at $5 \%$ level.

Source: Field survey, 2014 
The results of the test of the hypothesis, there is no statistically significant difference between mean incomes of the FUG crop farmers tested with Paired Samples T-test of MANITAB STATISTICS, (Table 3) indicated the existence of significant differences between the mean incomes of these crop farmers before and after joining the Fadama project in Anambra State (T-cal 7.62 > T-tab. 2.10), Enugu State (T-cal 7.07 > T-tab 2.10) and Imo State (T-cal 6.47 > T-tab 2.10) at $5 \%$ level of significance. These results led to the rejection of the null hypothesis that the mean incomes realized by the crop farmers of Fadama User Groups (FUGs) before and after joining the project are not statistically and significantly different. The alternative hypothesis was then accepted which implies that there is a remarkable difference between the income levels of these crop farmers before and after joining the Fadama project.

\subsection{Productive Resources of the Farmers before and after Joining the Fadama Project}

The estimated values of the productive resources of the farmers before and after joining the Fadama III project presented in Table 4, indicates that in Anambra State, fertilizer took the highest amount with $\$ 3,092,970$ (55.18\%), followed by yams with $\$ 923,600$ (16.48\%), then rice with $\$ 765,500$ (13.66\%), with the least being cocoyam with $\$ 31,250$ (0.56\%). In Enugu State, yam seeds topped the list with $\$ 1,385,543.8$ (28.83\%), followed by fertilizer with $\$ 1,339,750$ (27.57\%), cassava with $\$ 873,628.75$ (17.08\%), and the least was maize with $\$ 10,500(0.25 \%)$. In Imo State, fertilizer took the highest amount with $\$ 1,953,550$ (31.24\%) followed by yams with $\$ 1,529,250$ (24.45\%), labour with $\$ 1,007,700$ (16.11\%), and the least was cash which was only $\$ 8,000(0.12 \%)$. A mean value of $\$ 58,380.86$, $\$ 67,459.28$, and $\$ 86,568.19$ were expended on the productive resources accessed by the FUG crop farmers in Anambra, Enugu, and Imo, States respectively as productive resources before joining the project.

Table 4. Estimated Value of Productive Resources of the Farmers before and after Joining the Fadama Project

\begin{tabular}{|c|c|c|c|c|c|c|c|c|c|c|c|c|}
\hline \multirow[b]{3}{*}{ Variables } & \multicolumn{4}{|c|}{ Anambra } & \multicolumn{4}{|c|}{ Enugu } & \multicolumn{4}{|c|}{ Imo } \\
\hline & \multicolumn{2}{|l|}{ Before } & \multicolumn{2}{|c|}{ After } & \multicolumn{2}{|l|}{ Before } & \multicolumn{2}{|c|}{ After } & \multicolumn{2}{|c|}{ Before } & \multicolumn{2}{|c|}{ After } \\
\hline & 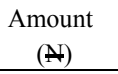 & $\begin{array}{c}\% \\
\text { of total } \\
\end{array}$ & $\begin{array}{c}\text { Amount } \\
(\mathbb{N})\end{array}$ & $\begin{array}{c}\% \\
\text { of total }\end{array}$ & $\begin{array}{r}\text { Amount } \\
(\mathbb{N}) \\
\end{array}$ & $\begin{array}{c}\% \\
\text { of total } \\
\end{array}$ & $\begin{array}{c}\text { Amount } \\
(\#) \\
\end{array}$ & $\begin{array}{c}\% \\
\text { of total } \\
\end{array}$ & $\begin{array}{c}\text { Amount } \\
\text { N) }\end{array}$ & $\begin{array}{c}\% \\
\text { of total } \\
\end{array}$ & $\begin{array}{c}\text { Amount } \\
(\mathbb{N})\end{array}$ & $\begin{array}{c}\% \\
\text { of total }\end{array}$ \\
\hline Rice & 765,500 & 13.66 & $4,737,500$ & 19.78 & 763,150 & 5.71 & 615,160 & 3.53 & - & - & - & - \\
\hline Yam & 923,600 & 16.48 & $3,033,000$ & 12.67 & $1,385,543.8$ & 28.53 & $4,823,600$ & 27.59 & $1,529,250$ & 24.45 & $3,710,730$ & 18.30 \\
\hline Maize & - & - & - & -- & 10,500 & 0.25 & 35,650 & 0.20 & 297,400 & 4.76 & $1,029,500$ & 5.08 \\
\hline Cocoyam & 31,250 & 0.56 & 48,000 & 0.20 & -- & -- & -- & - & 203,000 & 3,25 & 397,500 & 1.96 \\
\hline Cassava & 450,413 & 8.04 & $2,357,900$ & 9.84 & $873,628,75$ & 17.98 & $1,466,050$ & 8.39 & 566,440 & 9.06 & $2,361,800$ & 11.65 \\
\hline Plantain & 16,000 & 0.29 & 36,000 & 0.15 & - & - & -- & - & - & -- & - & - \\
\hline Vegetable & -- & - & - & -- & - & -- & -- & - & 321,200 & 5.14 & 730,350 & 3.60 \\
\hline Groundnut & - & - & - & -- & - & - & 56,300 & 0.33 & 248,650 & 3.98 & 563,700 & 2.78 \\
\hline Labour & 142,530 & 2.54 & $3,857,100$ & 16.16 & 18,100 & 0.37 & 56,300 & 0.33 & $1,007,700$ & 16.11 & $2,261,750$ & 11.15 \\
\hline Cash & 40,000 & 0.71 & $3,121,150$ & 3.04 & 122,900 & 2.52 & $4,584,053$ & 26.22 & 8,000 & 0.12 & $1,637,987$ & 8.08 \\
\hline Fertilizer & $3,092,970$ & 55.18 & $5,510,300$ & 23.02 & $1,339,750$ & 27.57 & $4,797,800$ & 27.44 & $1,953,550$ & 31.24 & $7,213,160$ & 35.57 \\
\hline $\mathrm{A} /$ chemicals & 142,300 & 2.54 & $1,232,800$ & 5.14 & 343,496 & 7.07 & $1,103,150$ & 6.32 & 118,600 & 1.89 & 371,000 & 1.83 \\
\hline Total & $5,604,563$ & 100 & $23,933,750$ & 100 & $4,857,068.5$ & 100 & $17,481,763$ & 100 & $6,253,790$ & 100 & $20,277,477$ & 100 \\
\hline Mean value & $58,380.86$ & & $249,309.90$ & & $67,459.28$ & & $242,802.26$ & & $86,568.19$ & & $281,631.62$ & \\
\hline
\end{tabular}

Source: Field survey, 2014.

The study also reveals that in the post project, in Anambra State, fertilizer took the highest amount productive resources expended by the farmers with $\$ 5,510,300(23.02 \%)$, followed by rice with $\$ 4,737,500$ (19.78\%), and labour with $¥ 3,857,100$ (16.16\%). Plantain took the least amount with $¥ 36,000(0.15 \%)$. In Enugu State, it was yam seeds with $\$ 4,823,600$ (27.59\%), closely followed by fertilizer with $\$ 4,797,800$ (27.44\%), labour with $¥ 4,584,051.81$ (26.22\%) while maize took the least amount with $\$ 35,650(0.20 \%)$. In Imo State, fertilizer topped the list with $\$ 7,213,160$ (35.57\%), followed by yam seeds with $¥ 3,710,730$ (18.30\%), and cassava with $¥ 2,361,800(11.65 \%)$ and the least was agrochemicals with $\$ 371,000$ (1.83\%). After joining the Project, the mean values expended on productive resources in Anambra, Enugu and Imo States were $\$ 249,309.90$, $\$ 242,802.26$, and $\$ 281,631.62$ respectively (Table 4). This is an injection of capital into the rural economy to help break the vicious poverty circle inherent in the economy and ensure greater productivity and enhanced income.

\subsection{Difference in Mean Values of Productive Resources of the FUGcrop Farmers before and after Joining the Fadama Project}

Hypothesis II, mean values of productive resources of the FUG crop farmers before and after joining the Fadama project are not significantly different was tested with Paired Samples T-test of the MINITAB statistical packages. The results presented in Table 5 showed existence of significant differences between the mean values of productive resources of the crop farmers before and after joining the Fadama project in Anambra State (T-cal 5.18 > T-tab. 2.10), 
Enugu (T-cal $5.83>$ T-tab 2.10) and Imo States (T-cal 10.26 > T-tab 2.10) at 5\% level of significance. These results led to the rejection of the null hypothesis that the mean values of productive resources used by the FUG crop farmers before and after joining the project were not significantly different. The alternative hypothesis was then accepted, implying that the Fadama project provided the FUG crop farmers more productive resources that enabled them to realize more income and better standard of living.

Table 5. Estimated Differences in Means of Productive Resources of Farmers Before and After Joining the Project

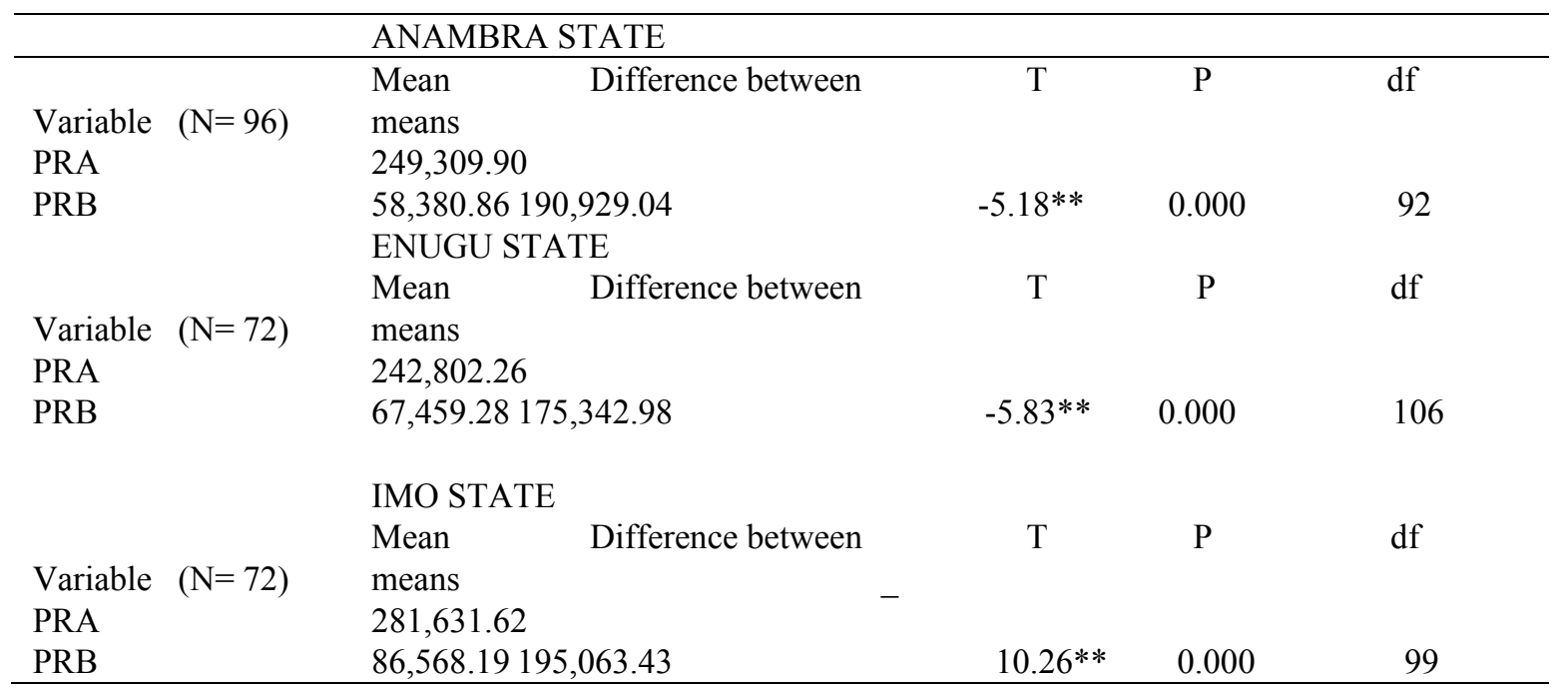

Notes: PRA $=$ Productive resources after joining the project $\mathrm{PRB}=$ Productive resources before joining the project. $\mathrm{N}=$ Number of respondents. $* *=$ Significant at $5 \%$ level.

Source: Field survey, 2014

\subsection{Estimated Determinants of the FUG Crop Farmers on their Annual Incomes before and after joining the Project}

The multiple regression analysis was used to establish the influence of socio-economic factors of the farmers on their annual incomes. Four functional forms (Linear, exponential, semi-log and double-log) of the regression model were fitted with the data and tried using the MANITAB statistical software. It could be seen from Tables 6 and 7 that the output of the linear form gave the best result in terms of number, sizes and signs of significant parameter estimates as well as $\mathrm{R}^{2}, \mathrm{R}^{2}$ (adjusted), F-statistic and Durbin-Watson statistic. It was therefore adopted as the lead equation. The regression equation is stated as:

$\mathrm{INC}=165167-786 \mathrm{EDU}+993 \mathrm{AGE}-13223 \mathrm{ASI}+3472 \mathrm{DTM}+$ 40992FFS -4149FAS + 13939ETV -21155GEN + $321 \mathrm{EXP}+85850 \mathrm{PDR}+\mathrm{e}^{\mathrm{i}}$

Table 6. Estimated Determinants of Farmers' Income before Joining the Project

\begin{tabular}{lllll}
\hline Parameter & Linear & Exponential & Semi-log & Double-log \\
\hline Constant & 165167 & 3.1241 & -276814 & 2.7132 \\
& $(1.79)$ & $(18.32)$ & $(-1.17)$ & $(5.06)$ \\
EDU & -786 & -0.008342 & -13622 & -0.0123 \\
& $(-0.20)$ & $(-0.58)$ & $(-1.48)$ & $(-0.07)$ \\
AGE & 993 & 0.001213 & 6756 & 0.0563 \\
& $(0.54)$ & $(0.56)$ & $(0.61)$ & $(1.15)$ \\
ASI & -13223 & -0.001679 & -2667 & -0.0452 \\
& $(-0.44)$ & $(-0.42)$ & $(-0.54)$ & $(-0.31)$ \\
DTM & 3472 & 0.00822 & 3365 & 0.08996 \\
& $(1.86)^{*}$ & $(0.74)$ & $(0.56)$ & $(1.08)$ \\
FFS & 40992 & 0.06814 & 188642 & 0.2856 \\
& $(2.39)^{* *}$ & $(2.05)^{* *}$ & $(2.38)^{* *}$ & $(2.04)^{* *}$ \\
FAS & -4149 & -0.006341 & -2761 & -0.09888 \\
\hline
\end{tabular}




\begin{tabular}{lllll}
\hline & $(-0.62)$ & $(-0.81)$ & $(-0.46)$ & $(-1.13)$ \\
ETV & 13939 & 0.009956 & 2448 & 0.2496 \\
& $(2.40)^{* *}$ & $(2.13)^{* *}$ & $(2.11)^{* *}$ & $(1.87)^{*}$ \\
GEN & -21155 & -0.002113 & -30176 & 0.03842 \\
& $(-0.93)$ & $(-0.82)$ & $(-1.14)$ & $(0.32)$ \\
EXP & 321 & 0.002711 & 2746 & 0.0866 \\
& $(0.19)$ & $(0.58)$ & $(0.38)$ & $(0.78)$ \\
PDR & 85850 & 0.000145 & 8965 & 0.3049 \\
& $(1.89)^{* *}$ & $(1.14)$ & $(2.13)^{* *}$ & $(2.11)^{* *}$ \\
$\mathrm{R}^{2}$ & $68.7 \%$ & $62.5 \%$ & $65.3 \%$ & $64.5 \%$ \\
$\mathrm{R}^{2}$ (adj) & $64.7 \%$ & $60.1 \%$ & $62.7 \%$ & $62.6 \%$ \\
F-statistic & 4.79 & 4.12 & 4.23 & 4.13 \\
D-W statistic & 1.78 & 1.56 & 1.67 & 1.47 \\
\hline = Significant at $1 \%$ level; $* *$ Significant at 5\% level. Figures in $($ ) are tratios. EDU, AGE, ASI, DTM, FFS,
\end{tabular}

Notes: $*=$ Significant at $1 \%$ level; $* *=$ Significant at $5 \%$ level. Figures in ( ) are $t$ ratios. EDU, AGE, ASI, DTM, FFS, FAS, ETV, GEN, EXP and PDR are as earlier defined. D-W statistic $=$ Durbin-Watson statistic.

Source: Field survey 2014.

Table 7. Estimated Determinants of Farmers' Income after Joining the Project

\begin{tabular}{lllll}
\hline Parameter & Linear & Exponential & Semi-log & Double-log \\
\hline Constant & 644672 & 2.7812 & -23614 & 1.9431 \\
& $(1.81)$ & $(13.14)$ & $(-0.98)$ & $(4.07)$ \\
EDU & -16054 & -0.00813 & -13438 & -0.0112 \\
& $(-1.80)$ & $(-0.63)$ & $(-1.25)$ & $(-0.08)$ \\
AGE & 6233 & 0.00213 & 5667 & 0.0449 \\
& $(1.23)$ & $(0.55)$ & $(0.73)$ & $(1.13)$ \\
ASI & -10398 & -0.00412 & -1769 & -0.0461 \\
& $(-0.12)$ & $(-0.47)$ & $(-0.57)$ & $(-0.42)$ \\
DTM & 9755 & 0.00916 & 2887 & 0.0761 \\
& $(1.98)^{*}$ & $(0.77)$ & $(0.61)$ & $(1.11)$ \\
FFS & 39989 & 0.07116 & 176178 & 0.2671 \\
& $(2.40)^{* *}$ & $(2.07)^{* *}$ & $(2.09)^{* *}$ & $(1.98)^{* *}$ \\
FAS & -15795 & -0.00043 & -2476 & -0.0891 \\
& $(-0.85)$ & $(-0.68)$ & $(-0.52)$ & $(-1.14)$ \\
ETV & 8322 & 0.08341 & 23641 & 0.2187 \\
& $(1.83)^{* *}$ & $(2.14)^{* *}$ & $(2.08)^{* *}$ & $(1.94)^{*}$ \\
GEN & -68232 & -0.00781 & -33672 & 0.0271 \\
& $(-1.09)$ & $(-0.69)$ & $(-1.08)$ & $(0.46)$ \\
EXP & -2776 & 0.00347 & 2697 & 0.0674 \\
& $(-0.61)$ & $(0.64)$ & $(0.51)$ & $(0.83)$ \\
PDR & 55461 & 0.00136 & 7729 & 0.1973 \\
& $(2.15)^{* *}$ & $(1.12)$ & $(2.11)^{* *}$ & $(1.96)^{* *}$ \\
R & $74,6 \%$ & $68.4 \%$ & $65.9 \%$ & $70.7 \%$ \\
R ${ }^{2}$ (adj) & $70.4 \%$ & $64.4 \%$ & $63.4 \%$ & $68.2 \%$ \\
F-statistic & 8.09 & 4.21 & 4.14 & 7.04 \\
D-W statistic & 1.86 & 1.58 & 1.63 & 1.92 \\
\hline
\end{tabular}

Notes: * = Significant at $1 \%$ level; $* *=$ Significant at $5 \%$ level. Figures in ( ) are $t$ ratios. EDU, AGE, ASI, DTM, FFS, FAS, ETV, GEN, EXP and PDR are as earlier defined. D-W statistic = Durbin-Watson statistic.

Source: Field survey 2014

A total of 10 regressors were included in the model and four of them, distance to the market (DTM), farmers' farm size (FFS), extension visits (ETV) and productive resources (PDR) were statistically significant. Distance to the market was significant at $1 \%$ level of probability at both before and after joining the Fadama project. This factor is an important determinant of the income of any farmer in that should there be no market for his products, the products 
will either spoil or he will be forced to give them away at any offer without an opportunity to optimize his income from the sales. Again the nearer the market the smaller the transportation cost and the higher the net income. This is probably the reason behind the construction of Fadama markets in some communities as community projects.

Farmer's farm size, extension visits and productive resources were significant at 5\% level of probability. This implies that the FUG crop farmers who used more of these resources were likely to realize more income. This result agrees with Kern and Paulson (2011) who postulated that profit does vary with farm size as larger farms may be able to more efficiently use larger equipment complements or obtain discounts by buying larger volumes of inputs resulting in lower capital and/or variable input costs per acre.

Improved farming technologies such as high yield crop varieties, chemical fertilizers, and irrigation techniques have been central in raising yields, however, farmers have been much slower in adopting these new methods because of lack of information regarding how to apply the improved inputs (Betz, 2007). Consequently, access to reliable information is an integral part in any farmer's ability to raise productivity. This probably explains the significance of extension visits (EVT) in this result. Application of high yield crops, good irrigation and suitable agrochemicals will increase the productivity of any farmer; tractorization will save time and cost cumulating in improved income. This underlines why in this result, productive resources (PDR) was significant.

The $\mathrm{R}^{2}$ values of $68.7 \%$ and $74.6 \%$ before and after joining the project respectively showed that $68.7 \%$ and $74.6 \%$ of the variations in the income levels were explained by the explanatory variables and buttressed by $R^{2}$ (adj) of $64.7 \%$ and $70.4 \%$ for before and after joining the Fadama project respectively. It also showed an F- statistic of 4.79 and 8.09 respectively significant at $5 \%$ level implying the goodness of fit of the model and confirmed by Durbin-Watson statistic of 1.78 and 1.86 respectively which signify the absence of auto-correlation among observations of the independent variables. The result led to the rejection of the null hypothesis that the socio-economic characteristics of the FUG crop farmers have no statistical and significant effects on their incomes and the acceptance of the alternative hypothesis which is that socio-economic characteristics of the FUG crop farmers have statistical and significant effects on the farmers income both before and after joining the Fadama Project.

The Chow-statistic was used to test whether the independent variables have different impact on the crop farmers' income before and after joining the project.

The Chow-test $=\left\{\underline{S}_{A B P}-\left(\underline{S}_{A P}+\underline{S}_{B P}\right)\right\} /(K)$

$$
\left(\mathrm{S}_{\mathrm{AP}}+\mathrm{S}_{\mathrm{BP}}\right) /\left(\mathrm{N}_{\mathrm{AP}}+\mathrm{N}_{\mathrm{BP}}-2 \mathrm{~K}\right)
$$

Where

$\mathrm{S}_{\mathrm{ABP}}=$ Sum of squared residuals from the pooled data of the crop farmers'income regression output before and after joining the project;

$\mathrm{S}_{\mathrm{AP}}=$ Sum of squared residuals from the crop farmers' income regression output after joining the project;

$\mathrm{S}_{\mathrm{BP}} \quad=$ Sum of squared residuals from the crop farmers' income regression output before joining the project;

$\mathrm{N}_{\mathrm{AP}}=$ Number of observations after joining the project;

$\mathrm{N}_{\mathrm{BP}}=$ Number of observations before joining the project;

$\mathrm{K}=$ Total number of parameters.

The Chow-statistic gave a p value of 1.21, 0.87, and 0.92 for Anambra, Enugu and Imo States respectively which in each case is greater than 0.05 at 5 percent level of significance. This shows that there is no statistical significant difference in the impact of the socio-economic variables on the income of the crop farmers before and after joining the project.

\subsection{Constraints to Project Realization}

Crop farmers within the three States of study (Anambra, Enugu, and Imo) posited that Fadama III Project could have recorded more successes if not for some constraints. Analysis of these constraints done by comparing the calculated mean scores of the variables with the critical mean of 2.0 obtained using a 5-point Likert scale (Table 8) were ranked in order to determine the seriousness of the constraints. The crop farmers considered irregular fund disbursement method as the greatest set back with a mean score of 3.83 . 
Table 8. Constraints to Project Realization

\begin{tabular}{lll}
\hline Variable & Mean score & Rank \\
\hline Irregular fund disbursement method & 3.83 & $1^{\text {st }}$ \\
Late release of government cash contribution & 3.44 & $2^{\text {nd }}$ \\
Demand for users' cash contribution & 3.12 & $3^{\text {rd }}$ \\
Nonpayment of beneficiary contribution & 3.09 & $4^{\text {th }}$ \\
Misconception of the project by benefiting communities & 2.82 & $5^{\text {th }}$ \\
Inadequacy of facilitators & 2.61 & $6^{\text {th }}$ \\
Inadequate logistics for facilitators/officers & 2.60 & $7^{\text {th }}$ \\
Internal wrangling/suspicion among benefiting communities & 1,56 & $8^{\text {th }}$ \\
Poor leadership/management by officers of FCAs/FUGs & 1.40 & $9^{\text {th }}$ \\
\hline
\end{tabular}

Source: Field survey, 2014.

The other problems were listed in a descending order with their mean scores: late release of government cash contribution 3.44; demand for users' cash contribution 3.12; nonpayment of beneficiary contribution 3.09; misconception of the project by benefiting communities 2.82; inadequacy of $\backslash$ facilitators 2.61 ; inadequate logistics for extension staff/officers 2.60; internal wrangling/suspicion among benefiting communities 1,56 and poor leadership/management by officers of FCAs/FUGs 1.40 .

\section{Conclusion}

Fadama III project is an applaudable intervention project adopting Community Driven Development approach to rural development. It empowered the users through collective decision-making to effectively and efficiently allocate and manage resources for their livelihood activities. The demand-responsive structure of the project grants community organizations as much decision-making authority as possible and promoted community ownership of and responsibility for operations and maintenance of infrastructure investments in their locality. This will change the psychosocial life of the communities and improve their perception of life. The estimated difference in means of income of farmers before and after joining the project in the three states of study (Table 5), shows that the project has satisfied one of its objectives of sustainably increasing the incomes of Fadama resource users through effective and efficient delivery of productive resources directly to them. The mean values expended on productive resources after joining the Project in Anambra, Enugu and Imo States ( $\$ 249,309.90$, $\$ 242,802.26$, and $\$ 281,631.62$ ) respectively (Table 4) constitute an injection of capital into the rural economy. This will help break the vicious poverty circle inherent in the economy and ensure greater productivity, enhanced income and improved living standard.

The study reveals that the farming business is dominated by an age bracket considered to be economically active and highly productive. This implies that Fadama III project has successfully aided a reduction in rural unemployment which is an indication of development. The Project, by being gender sensitive (Table 1), has empowered the female gender and exposed them to income yielding venture like farming. This will help in no small measure in freeing them from servitude and male chauvinism which had been the bane of rural women in Nigeria.

\section{Recommendations}

It will be very ideal if the Project allocates its resource delivery for the production of crops in the States in order of their income yielding capabilities. Early and prompt release of productive resources and cash counterpart contributions to the farmers, provision of more extension agents, services and logistics for the farmers and reduction of users' cash contribution will ensure improved productivity, income and project sustainability

State governments and State Fadama Coordination Offices should mount vigorous public enlightenment campaign to educate the communities on the advantages of the project to community development. The Project should step up its capacity building support for community organizationsto upgrade their skills and acquire new ones to support demand-driven community investments.

State governments should increase their matching grant fund to Fadama User Groups (FUGs) to finance acquisition of assets for income-generating activities. This will increase value added from the products produced by their members and diversify their sources of livelihood. The matching grant will actually help reduce their vulnerabilities and risks, thereby making them more attractive to formal financial institutions. 


\section{References}

Adeyemi, A. (2011). Imo State -Eastern Heartland. Retrieved from http://www.cometonigeria.com/search-by-region/south-east/imo-state/

African Development Fund. (2003). Republic of Nigeria Fadama DevelopmentProject Appraisal Report. Tunisia. ADF publication.

Ajayi, A. R., \& Nwalieji, A. H. (2010). Impact of the Anambra State Fadama ProjectPhase-1 on the Socio-economic Life of the Rural Farmers. Retrieved from http://www.krpublishers.com/02-Journals/JHE/JHE-29-0-000-10-web

Anon. (2004). What are wetlands. Retrieved from http:/www.ramsar.org/about-infopack- ie-htm

Blench RM., \& Ingawa SA. (2004). A practical Guide for National Fadama Development Project IIon conflict and management: Government of Nigeria PCU Fadama II/World Bank, pp. 1 - 19.

Canback D. (2008). Canback global income database. Somerville. Canback Dangel LLC.

Chavez, E. M. (2003). Increasing productivity of rural work. Economic and Social Council (ECOSOC) Round Table. New York, United Nations publication.

Dick, Gregorio, \& McCarthy. (2004). Political institutions and development: Failedexpectations and renewed hopes. Massachusetts, USA Edward Elgar Publishing Ltd.

Ebewore, S.O. (2010). Assessment of loan administration by a micro finance bank. Journal of Research in National Development, 8(2), 125-136.

Echeme, I.I., \& Nwachukwu, C.C. (2010). An investigation of Fadama 11 Projectimplementation in Imo State. American Journal of Scientific and Industrial Research, 1(3), 532-538.

Enugu State Fadama Coordination Office (2010). Information handbook. Enugu, Enugu State Government Press Ltd.

Federal Ministry of Agriculture and Water Resources (FMAWR) (2009). Third National Fadama Development Project, Manual. Vol. 1(1), Abuja. National Fadama Coordinating Office.

Henri-Ukoha, A., Ohajianya, D.O., Nwosu, F.O., Onyeagocha, S.U.O., \& Nwankwo, U.E. (2011). Effect of World Bank assisted Fadama 11 Project on the performance of fish farming in Imo State, South East Nigeria. American Journal of Experimental Agriculture, 1(4), 450-457. http://dx.doi.org/10.9734/AJEA/2011/589

Ike, P.C., \& Uzokwe, U.N. (2011). Estimation of Poverty among Rural FarmingHouseholds in Delta State, Nigeria. International Journal Agriculture and Food Science Technology, 2(1), 11-21.

Kern, M., \& Paulson, N. (2011). Profitability and farm size on grains farms in Illinois. Retrieved from http://farmdocdaily.illinois.edu/2011/05/profitability-and-farm-size-on.html

Marshal, G. (1988). A dictionary of sociology. New York, Oxford University Press.

Nkonya, E., Philip, D., Mogues, T., Pander, J., Yahaya, M.K., Adebowale, (...) \& Kato, E. (2008). Impacts of pro-poor Community-Driven Development Project in Nigeria. Washington, IFPRI Publications.

Nwachukwu, I. N., Agwu, N.M., Ezeh, C.I., Mbanasor, J. A., Onyenweaku, C.E., \& Kamalu, C.E. (2009). Evaluation of Second National Fadama Project in Nigeria: A rapid policy appraisal. Retrieved from http://mpr.ub.unimuenchen.de/12914/MPRAPaper No.12914

Oxford University (2014). Oxford Dictionary. London: Oxford University Press.

Pandolfelli, L., Meinzen-Dick, R., \& Dohrn, S. (2008). Gender and Collective Action: Motivations, Effectiveness and Impact. Journal of International Development, 20(1), 1-116. http://dx.doi.org/10.1002/jid.1424

Tajfel, H., \& Turner, J. C. (1979). An integrative theory of inter-group conflict. In Austin, W. G \&Worchel, S (Ed.), The Social Psychology of Inter-group Relations (pp33-47). CA: Brooks/Cole.

Umebali, E.E. (2008). Rural Development and Management. (MPA 736). Lagos. National Open University of Nigeria.

Wikipedia Organisation (2013). Anambra State. Retrieved from http://en.wikipedia.org/wiki/Anambra_State

Wilson \& Wide (2003). Participation: A theoretical context. Retrieved from http://www.cagconsultants.co.uk/resources/communities/Participation_Theoretical_Frameworks

Wright, S.C., Taylor, D.M., \& Moghaddam, F.M. (1990). Responding to membership in adisadvantaged group: From acceptance to collective protest. Journal of Personality and Social Psychology, 58(6), 994-1003. http://dx.doi.org/10.1037/0022-3514.58.6.994 